\title{
A STUDY ON CONSUMER ADOPTION OF MOBILE WALLET WITH SPECIAL REFERENCE TO EMPLOYEES OF IT SECTOR IN COIMBATORE
}

KEY WORDS: Mobile Wallet Digital Payment, Coimbatore.

\section{Dr. G Jayanthi}

\section{Sreeanandan*}

\section{Baranipriya $\mathbf{A}$}

Assistant Professor, Department Of Economics, PSG College Of Arts \& Science, Coimbatore

PhD Research Scholar, Department Of Economics, PSG College Of Arts \& Science, Coimbatore *Corresponding Author

$\mathrm{PhD}$ Research Scholar, Department Of Economics, PSG College Of Arts \& Science, Coimbatore

In the world, the digital payment sector is one of the sectors that develop in every second; it gives unimaginable services through internet. Banking sector is the main stream which benefits positively helps to make transactions any time. At present so many payment systems are available, among them mobile wallet play a significant role. The paper studies the adoption of mobile wallet among the IT sector employees in Coimbatore. The study reveals security issues, identity theft, delay in payment are the main problem which was found during transaction. Apart from these issues the convenience, accessibility, and ease of use have gained a credit to mobile wallet. As the youth population adapt to latest technology quickly so M-wallet service providers must consider the needs of the customers.

\section{INTRODUCTION}

In today's world smart phone has become an important part of life. Number of smart phone users has increased dramatically as it has become more affordable. According to data released by TRAI there are around 300 million users of mobile phone in India. Besides providing the basic function of communication there are plenty of services a smart phone provides. These services include socialization internet access services and even payment services. For using payment services on smart phones and application for the same is required to be installed in it. This application is called the digital wallet or electronic wallet or popularly mobile wallet. Its functions of keeping and paying the currency are same as of traditional leather wallet with the only difference of performing the same digitally and more number of parties directly or indirectly involved in performing the same on digital platform.

The mobile wallet money is used in the various areas of the world business like Banks, Customers and Companies. The Banks have taken a better position in providing a better transaction services and payment to the customers' requirement. The customers are dragged by the shopping facilities that are given by mobile wallet and are attracted because of convenience and speedy transaction. In case of companies, they aim at providing facility of transaction services and payment choice to their clients and the multiple payment combination facility are attached to mobile wallet service.

\section{DIGITAL PAYMENT MODES IN INDIA}

There are several mode of digital payment available in India. These are:

ONLINE OR MOBILEWALLETS:

PREPAID CREDIT CARDS.

DEBIT/RUPAY CARDS:

AEPS:The Aadhaar Enabled Payment System.

\section{USSD:}

Unstructured Supplementary Service Data based mobile banking.

\section{UPI: The United Payments Interface}

\section{DEFINITION OF IMPORTANT CONCEPTS IN MOBILE WALLET IN INDIA DIGITAL PAYMENT-}

Digital payment is a way of payment which is made through digital modes. In digital payments, payer and payee both use digital modes to send and receive money. It is also called electronic payment. All the transactions in digital payments are completed online. It is an instant and convenient way to make payments.

\section{E-WALLET-}

E-wallet is a type of electronic card which is used for transactions made online through a computer or a smart phone. Its utility is same as a credit or debit card. An E-wallet needs to be linked with the individual's bank account to make payments. e-Wallet is to making paperless money transa ction.

\section{MOBILEWALLET (M-WALLET) -}

A mobile wallet is a Pre-paid Purchase Instrument (PPI), also referred to as virtual wallet that stores payment card information on a mobile device. Mobile wallets can be used at merchants listed with the mobile wallet service provider.

\section{IT EMPLOYEES AND USA GE OF MWALLET}

IT employees are the main agent to develop software sector. These software sectors include software development, solution to the internet based problems and this sector is very helpful for the banking and other allied activities. M Wallet is purely an internet technological achievement of the software sector and most of the IT employees are using these facilities to simplify their life.

\section{OBJECTIVES OFTHE STUDY}

- To study the socio-economic condition of m-wallet users in IT Sector.

- To analyse the factors influencing the consumers to adoption of M-wallet.

- To identify the problems faced by consumers in the use of M-wallet.

\section{STATEMENT OF THE PROBLEIM}

M-Wallet payments are becoming more compatible for the Indian economy guided by Smart phone pivotal internet utilization. Mobile wallets are changing the traditional ways of making and receiving payments, doing shopping, paying bills etc. Employees belonging to IT Sector want fast food, fast fuel and fastness in everything. Especially, this generation has grown up in a world with technology, connected with social media networks using their smart phones and tablets. Though lot of research work has been conducted on the use of mobile wallet minuscule amount of research has been done on the same with IT Sector employees as the respondents. This research study is a humble attempt in this direction to know the preference of

\begin{tabular}{l|l}
\hline December, 2019 & Publication : $15^{\text {th }}$ February, 2020
\end{tabular} 
employees of IT Sector towards mobile wallets.

\section{DATA SOURCES AND METHODOLOGY}

The present study aims to understand "Consumer Adoption of Mobile Wallet with special reference to IT Sector". Hence the study is both analytical and descriptive in nature. There are 70,000 employees working in IT Sector in Coimbatore. The present study is based on Primary Data. The data was collected only from 70 IT Employees from Tidel Park, Keeranatham and saravanampatti IT park using Stratified Random Sampling. The data was collected from the IT Industry Employees through Interview Schedule. For analysis purpose Percentage, Likert Scale, and Garrett Ranking Technique were used.

\section{FINDINGS AND ANALYSIS}

The classification of the respondents according to their socioeconomic condition is given in the following table.

Table 1 Socio-Demographic Profile of the Respondents

\begin{tabular}{|c|c|c|c|c|}
\hline \begin{tabular}{|l|} 
S \\
No
\end{tabular} & Variables & Particulars & $\begin{array}{l}\text { No of } \\
\text { respondents }\end{array}$ & Percentage \\
\hline \multirow[t]{5}{*}{1} & \multirow[t]{5}{*}{ Age } & $\begin{array}{l}\text { Below } 20 \\
\text { years }\end{array}$ & 0 & 0 \\
\hline & & $20-30$ years & 68 & 97 \\
\hline & & $30-40$ years & 2 & 3 \\
\hline & & \begin{tabular}{|l} 
Above 40 \\
years
\end{tabular} & 0 & 0 \\
\hline & & Total & 70 & 100 \\
\hline \multirow[t]{4}{*}{2} & \multirow{4}{*}{\begin{tabular}{|l} 
Marital \\
Status
\end{tabular}} & Married & 9 & 13 \\
\hline & & Unmarried & 60 & 86 \\
\hline & & Divorced & 1 & 1 \\
\hline & & Total & 70 & 100 \\
\hline \multirow[t]{2}{*}{3} & \multirow[t]{2}{*}{$\begin{array}{l}\text { Education } \\
\text { Qualification }\end{array}$} & $\begin{array}{l}\text { Up to } 12^{\text {th }} \\
\text { standard }\end{array}$ & 0 & 0 \\
\hline & & \begin{tabular}{|l} 
UG \\
Professional
\end{tabular} & 36 & 52 \\
\hline
\end{tabular}

\begin{tabular}{|l|l|l|l|l|}
\hline \multirow{2}{*}{} & & $\begin{array}{l}\text { PG } \\
\text { Professional }\end{array}$ & 21 & 30 \\
\cline { 3 - 5 } & Others & 13 & 18 \\
\cline { 3 - 5 } & Total & 70 & 100 \\
\hline \multirow{4}{*}{4} & \multirow{3}{*}{$\begin{array}{l}\text { Ssage of } \\
\text { Smart Phone }\end{array}$} & Yes & 69 & 99 \\
\cline { 3 - 5 } & No & 1 & 1 \\
\cline { 3 - 5 } & Total & 70 & 100 \\
\hline
\end{tabular}

\section{Source: Field Survey}

For the purpose of this study, age of the respondents has been classified into four i.e., below 20 years, $20-30$ years, 30-40 years above 40 years. 97 percent of the respondents belong to the category of $20-30$ years followed by 3 percent from the age group of 30-40 years. None of the respondents are belongs to below 20 and above 40 years of age. This shows that the fresh graduates are more prominent in IT sector. The marital status of the respondents has been classified into four categories i.e Married, Unmarried and Divorced. Most of the respondents were Unmarried (86 percent) followed by Married (13 percent) and Divorced ( 1 percent). Since most of the respondents belong to 20-30 age group and fresh graduates most of them were unmarried. IT is a sector where employees are recruited on the basis of their technical knowledge. So majority of the respondents were UG professionals (51\%) and 30 percent of the respondents are completed PG professionals and rest of them were completed nonprofessional courses like Bcom, Bsc and BA. From the area of study, it is observed that most of the respondents were smart phone users (99 percent). Only a very few respondents do not use smart phone (1\%).

\section{FACTORS INFLUENCING TO USE M-WALLET PAYM ENTS SERVICES WEIGHTED AVERAGE SCORE}

Weighted Average method was applied to analyze the factors influencing the M-Wallet users to use the M-Wallet payment gateway in Coimbatore city with special reference to IT employees. The sample respondents were asked to give their opinion about the factors influencing them to use M-Wallet on five point rating scale. The analysis of the Weighted Average is shown in the table.

Table 2 Influence Level Towards M-Wallet Payment Services

\begin{tabular}{|c|c|c|c|c|c|c|c|}
\hline S.No & Variables & $\begin{array}{c}\text { Extremely } \\
\text { Influencing }\end{array}$ & $\begin{array}{c}\text { Very } \\
\text { Influencing }\end{array}$ & $\begin{array}{l}\text { Somewhat } \\
\text { Influencing }\end{array}$ & $\begin{array}{c}\text { Slightly } \\
\text { Influencing }\end{array}$ & $\begin{array}{c}\text { Not } \\
\text { Influencing }\end{array}$ & $\begin{array}{l}\text { Weighted } \\
\text { Average } \\
\text { Score }\end{array}$ \\
\hline 1 & Accessibility & 25 & 23 & 7 & 6 & 2 & 4 \\
\hline 2 & $\begin{array}{c}\text { Convenience in buying } \\
\text { products }\end{array}$ & 10 & 23 & 25 & 3 & 2 & 4 \\
\hline 3 & Security and privacy & 9 & 22 & 24 & 7 & 1 & 3 \\
\hline 4 & Technology adoption & 20 & 17 & 16 & 9 & 1 & 4 \\
\hline 5 & Budgeting & 16 & 17 & 14 & 11 & 5 & 3 \\
\hline 6 & $\begin{array}{c}\text { Availability/acceptance } \\
\text { of the services at } \\
\text { different stores }\end{array}$ & 8 & 20 & 17 & 11 & 7 & 3 \\
\hline 7 & $\begin{array}{c}\text { MI-Wallet substitute the } \\
\text { physical payment } \\
\text { system }\end{array}$ & 16 & 29 & 15 & 3 & 0 & 4 \\
\hline 8 & $\begin{array}{c}\text { Confidentiality of bank } \\
\text { details }\end{array}$ & 12 & 16 & 23 & 11 & 1 & 3 \\
\hline
\end{tabular}

Source: Field Survey

From the above table, the mean value obtain is mostly 3 and 4 which indicates somewhat influencing and very influencing respectively. The factor like Accessibility, Convenience in buying products, technology adoption, M-Wallet substitutes the physical payment system is very influencing the IT employees to use the MWallet for payment. Other factors like Security and Privacy, Budgeting, Availability/Acceptance of the services at different stores, confidentially of bank details, $24 * 7$ customer service are somewhat influencing to use the $M$
Wallet.

\section{PROBLEMS FACED THROUGH M-WALLET PAYMENT} SERVICE

To find out the most significant problem faced through mwallet payment services, Garrett's ranking technique was used. As per this method, respondents have been asked to assign rank for the problems and outcomes of such ranking have been converted into score value with the help of the following formula. 
Percent Position $=\frac{R_{i j}-0.5}{N_{i j}}(100)$

Table 3 Problems Faced Through M-Wallet

\begin{tabular}{|c|c|c|c|}
\hline S.No & $\begin{array}{c}\text { Problems Faced Through } \\
\text { M-Wallet }\end{array}$ & $\begin{array}{c}\text { Garrett } \\
\text { Score }\end{array}$ & Rank \\
\hline 1 & Time consuming & 3275 & 2 \\
\hline 2 & Lengthy procedure & 2969 & 6 \\
\hline 3 & Identify theft & 3056 & 3 \\
\hline 4 & Security breaches & 3484 & 1 \\
\hline 5 & Chances of loopholes & 2894 & 7 \\
\hline 6 & $\begin{array}{c}\text { Cannot be used for all } \\
\text { payments }\end{array}$ & 3021 & 4 \\
\hline 7 & Any others & 3010 & 5 \\
\hline
\end{tabular}

Source: Field Survey

From the above table, the problem faced by the respondents while using M-wallet is clearly analysed. As most of the respondents have opted Security breaches as major problem among others, it is considered as first rank followed by second rank for time consuming, third rank for identity theft, fourth rank for cannot be used for all payments, fifth rank for Network problem, Refund \& Fear of losing personal data, sixth rank for lengthy procedure and finally seventh rank for chances of loopholes as that is least rank.

\section{CONCLUSIONS}

Mobile wallet usage awareness was spread among the young people in India due to improvement in the smart phone technology. But still people are not aware about the varieties of services that it provides. The security issues, identity theft, delay in payment are the main problem which was found during transaction. Apart from these issues the convenience, accessibility, and ease of use have gained a credit to mobile wallet. As the youth population adapt to latest technology quickly, M-wallet service providers must consider their needs.

\section{REFERENCES}

1. Abrazhevich D (2001), "A survey of user attitudes towards electronic payment systems. The 15th Annual Conference of the Human Computer Interaction Group of the British Computer Society, IHM-HCI-200l", vol. 2. (pp. 69-71). Toulouse, France: Cepadues-Editions.

2. Ahuja \& Joshi (2018), "Consumer Perception toward Mobile Wallet, IJRDOJournal of Business Management", vol.4, issue. 1, pp. 52-60.

3. Carr M (2007) Mobile Payment Systems and Services: An introduction Forum, Institute of Development and Research in Banking Technology (IDRBT).

4. Chen L (2008) A model of consumer acceptance of mobile payment, International Journal Mobile Communication, Vol 6, Issue 1,pp 35-52.

5. Chakravorti S (2008) Theory of Credit Card Networks: A Survey of the literature, Review of Network Economics, Vol.2, issue.2 